Policy Research Working Paper 2081

Reforming Côte d'Ivoire's Cocoa Marketing and Pricing System

John McIntire

Panos Varangis
Fully liberalizing Côte

d'voire's export marketing system is expected to improve producers' incomes and marketing efficiency. And the benefits from liberalization should outweigh the costs from eliminating fixed producer prices and public forward sales.

The World Bank

Abidjan Resident Mission and

Development Research Group

Rural Development

March 1999 


\section{Summary findings}

Cote d'Ivoire has historically taxed cocoa producers. Market reforms over the past 10 years have somewhat succeeded in making domestic and foreign marketing more transparent and competitive. But they have not done much to raise producer prices in real terms or as a share of the FOB (free on board) price. Maintaining fixed producer prices and marketing costs and margins has encouraged rent-seeking and led to efficiency losses.

New reforms will fully liberalize the country's export marketing system by eliminating public management of exports. This means the end of mandatory export authorization, of public forward sales, and of fixed minimum producer prices and marketing margins.

The new reform is expected to improve producers' incomes.
McIntire and Varangis find that the benefits from the new reform (in terms of lower implicit taxes, lower marketing costs and margins, and higher producer prices: will outweigh the costs from eliminating public forward sales and fixed producer prices.

Results from a general equilibrium model indicate that reducing export taxes would have a small negative effect on aggregate income but would improve income distribution for poorer rural areas.

The fact that Côte d'Ivoire has market power in the world cocoa market justifies a higher optimal export tax than the current one. But raising export taxes may eventually reduce its market share and worsen income distribution, at the expense of the poorer rural sector.

This paper - a joint product of the Abidjan Resident Mission and Rural Development, Development Research Group -... is part of a larger effort in the Bank to evaluate the results of marketing and pricing reforms in producing countries. Copies of the paper are available free from the World Bank, 1818 H Street NW, Washington, DC 20433. Please contact Pauline Kokila, room MC3-547, telephone 202-473-3716, fax 202-522-1151, Internet address pkokila@worldbank.org. Policy Research Working Papers are also posted on the Web at http://www.worldbank.org/html/dec/Publications/Workpapers/ home,html. The authors may be contacted at jmcintire@worldbank.org or pvarangis@worldbank.org. March 1999. 266 pages)

The Policy Research Working Paper Series disseminates the findings of work in progress to encourage the exchange of iderts abous development issues. An objective of the series is to get the findings ont quickly, even if the presentations are iess than fully polished. The papers camy the names of the authors and should be cited accordingly. The findings, interpretations, and conclisions expressed in this paper are entirely those of the authors. They do not necessarily represent the view of the World Bank, its Executive Directors, or the countries they represent. 


\title{
Reforming Côte d'Ivoire's Cocoa Marketing and Pricing System
}

\author{
by John McIntire and Panos Varangis \\ The World Bank \\ Washington, DC 20433
}




\section{Introduction}

Cote d'Ivoire is the largest cocoa producer with a share of world production that grew from 23 percent in 1980 to 40 percent by 1997 and 1998. Since the record harvest of $1995 / 96$, cocoa has usually contributed some 35 to 40 percent of exports, 14 percent of GDP, and more than 20 percent of government income 1 . Production increases during the late 1980 s and 1990 s were mainly due to high producer prices in the $1980 \mathrm{~s}$, land availability for new plantings in the west of the country, elastic labor supply from poorer neighboring countries, and special government incentives. The plantings that matured in the 1990 s are projected to sustain production increases, and Ivorian market share, for the foreseeable future (ICCO 1998).

The Ivorian system has some flaws despite its recent successes to raise production and exports. An insistence on maintaining high producer prices against declining world prices in the late 1980s bankrupted the cocoa marketing system. In 1990, the government was forced to halve the producer price and it is still repaying debts to the private sector incurred in the late 1980s. Producer prices benefited little from the 100 percent devaluation of the CFA franc in 1994 and the real dollar price of cocoa in $1997 / 98$ crop season is less than the real dollar price of 1993/94, the last season before the devaluation. Government polices fix marketing costs and restrict competition, increasing intermediation costs and leaving a low percentage of the FOB price to farmers. The government's stabilization fund has accumulated large surpluses in years of relatively high world prices and these surpluses are not rebated to producers, thereby further reducing the producers' share of income from the crop.

The state has tried several reforms in the past decade. It sought to reduce its role in domestic and external marketing, to create a competitive environment for private agents, and to improve farmgate prices. Those reforms have failed to achieve a major objective however -- to increase producers' incomes in line with the FOB values of the crop.

This paper analyzes the key aspects of the Ivorian cocoa marketing and pricing system and evaluates new reform proposals. Section 1 analyzes the producer price policy focusing on the marketing cost structure and the level of producer prices. Section 2 examines the export sales focusing on the costs and benefits of publicly managed forward sales. Furthermore, this section analyzes the trade-off between fixed and variable producer prices. Section 3 evaluates the impact of lower export taxes and lower marketing costs and margins using a general equilibrium model of the Ivorian economy. Finally section 4 summarizes and concludes.

\footnotetext{
'In this paper we refer to "season" in the sense of the October through September marketing season; and to "year" as calendar year.
} 


\section{Producer Price Policy}

Private agents market and export cocoa within an administered price and cost structure. A public company (the Caisse de Stabilisation et de Soutien des Prix des Productions Agricoles, known as CAISTAB), regulates the structure with the goal of stabilizing prices so as to reduce income risks to market participants and to allow Cote d'Ivoire the benefits of forward sales ${ }^{2}$. CAISTAB controls the marketing chain from the point of purchase from farmers through export, including that of processed products such as cocoa liquor, butter and cake. It exercises its authority through an official cost schedule (barème ${ }^{3}$ ), which sets prices and margins for domestic marketing, and for export or sale to domestic processors. CAISTAB, in sum, determines profits and incomes in the Ivorian cocoa economy.

CAISTAB promulgates the barème at the beginning of each season. Table 1 shows the bareme for 1997-98. The barème starts with CAISTAB's assessment of the reference CIF price for the coming season, and works backward to the farm gate price. The reference CIF price is the weighted average of the price obtained in forward sales that cover 60-70 percent of exports and the projected spot price during the current season for the remaining $30-40$ percent. The reference CIF price is:

$$
\text { (1) } P_{C I F}=a p_{t-1}^{f}+(a-1) p_{t}^{s}
$$

where $P_{C I F}$ is the reference CIF price for season $\mathrm{t}$, a is the share of forward sales, $p_{t-1}^{f}$ is the forward price for the crop season $t$ negotiated during the previous season $t-$ 1 , and $p_{t}^{s}$ is the projected price for remaining $(1-a)$ spot sales during season $t$.

Following the estimation of the reference CIF price, CAISTAB deducts estimated maritime freight and insurance costs to arrive at an FOB price, which is guaranteed to exporters. Costs in the domestic marketing chain are then deducted from the guaranteed FOB price, based on "reasonable" costs and returns for each agent involved in domestic production and marketing -- exporters, processors, traders, transporters, and farmers.

\footnotetext{
${ }^{2}$ The direct predecessor of the current CAISTAB was created in 1962 when separate stabilization funds for coffee and cocoa, established in 1955, were merged. The current state company bearing the name Caisse de Stabilisation et de Soutien des Prix des Productions Agricoles was created in 1964 (Kouassi Atse, 1997).

${ }^{3}$ We use the French words for this and other expressions used commonly in the local trade.
} 
The barème further deducts the explicit specific export tax (known as the droit unique de sortie, or DUS) and CAISTAB's operating costs, including its substantial debt service, from the FOB price. The residual element in the calculation is then the producer price, which is set to satisfy the condition

(2) $P_{C I F}$ - maritime transport - DUS - direct domestic marketing costs

- CAISTAB operations $-P_{p}=S$

where $P_{p}$ is the producer price and $S$ is the stabilization margin. In theory $P_{p}$ is set so that $S$ is zero.

Table 1. Official cocoa export costs (barème) in 1997/98

\begin{tabular}{lcc}
\hline & CFAF / kg & $\begin{array}{c}\text { Percent of } \\
\text { FOB }\end{array}$ \\
\hline CIF price $\left(P_{C I F}\right)$ & 904 & 109 \\
- maritime transport costs & 75 & 9 \\
= FOB price & 829 & 100 \\
& & \\
- Export tax $(D U S)$ & 150 & 18 \\
- Direct domestic marketing costs & 115 & 14 \\
- CAISTAB operations & 49 & 6 \\
- Producer price $(P p)$ & 455 & 55 \\
= Stabilization margin $(S)$ & 61 & 7 \\
& & \\
\hline
\end{tabular}

Source: CAISTAB.

The historical objectives of price policy have been to keep producer prices stable and remunerative. Between 1980 and 1989, the stability objective was met in nominal terms by holding guaranteed nominal producer prices constant across seasons. The official producer price was set at $300 \mathrm{~F} / \mathrm{kg}$ from 1980 through 1983 , rose to 350 in 1984 , to 375 in 1985, and was held at 400 from 1986 through $1989^{4}$.

The goal of inter-annual price stabilization was abandoned in 1990 after the extended decline of world prices had made it impossible to maintain the producer price across seasons ${ }^{5}$. This is consistent with the argument of Deaton (1992) that inter-annual stabilization is difficult because slumps tend to last longer than booms; in such an asymmetrical market, even large stabilization funds go bust. Large funds also imply significant opportunity costs in other public investments as they must be held in

\footnotetext{
${ }^{4}$ Similar patterns were followed with coffee (Landell Mills 1996).

${ }^{5}$ Ruf (1996) discusses the cylical nature of the world cocoa market.
} 
liquid form. Moreover, as we show below, price stabilization has proven expensive to farmers.

Even if nominal price stabilization limited price volatility to producers it became fiscally unsustainable after the mid-1980s. The objective of producer price stabilization then changed from inter-annual stabilization to intra-annual stabilization (within seasons). Since 1990, Cote d'Ivoire has not attempted inter-annual price stabilization and it is unlikely that it will try to do so again.

The objective of remunerative producer prices has not been well met. Figure 1 compares Ivorian producer prices to world prices in real terms; the latter are represented by the International Cocoa Organization (ICCO) price converted to FOB Cote d'Ivoire. Following the collapse in 1990 from CFAF 400 to CFAF 200 per kg, producer prices remained low as a share of FOB. Though nominal prices rose after the 1994 devaluation and the (unrelated) recovery of world prices that began in 1993, nonetheless, real producer prices during the 1990s have been less than one-half of their 1980 levels. The difference between producer and FOB prices was enormous before 1987, became negative in 1988 and 1989, and has widened again since 1993.

Figure 1. Cote d'Ivoire -- Quarterly cocoa prices (1990 US \$/mt)

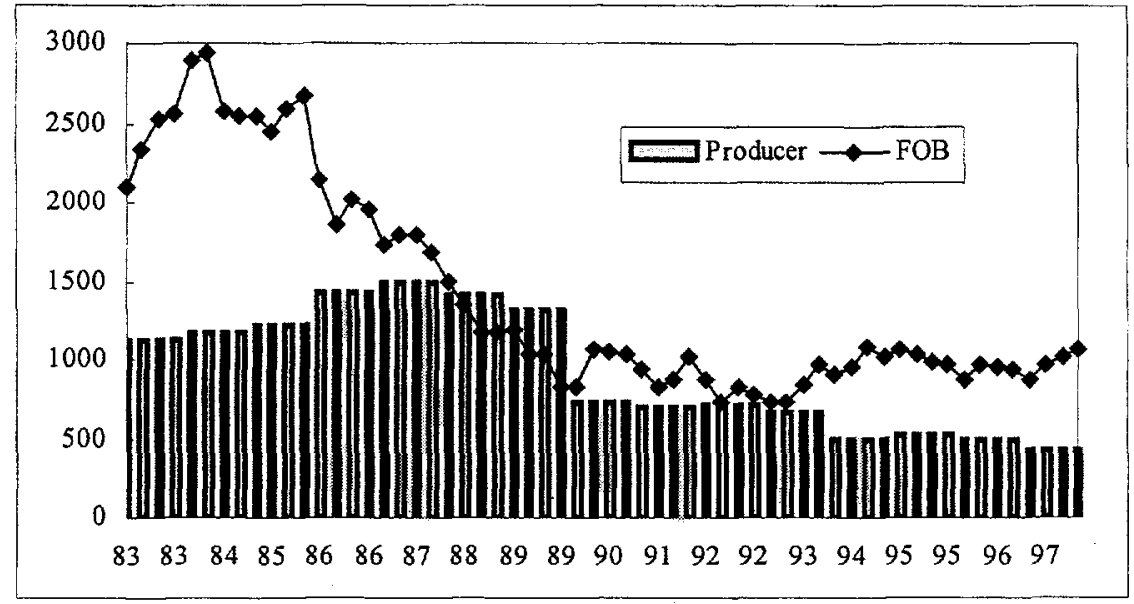

Source: Authors'calculations from World Bank (1998).

As a share of FOB, producer prices in Cote d'Ivoire have been low compared to those in other major producing countries. Data from 1995 (Figure 2) show that the share of the producer price in Cote d'Ivoire was smaller than any other major grower, with the exception of Ghana. Similar comparisons for 1997 showed that the producer share of the FOB price in Cote d'Ivoire and Ghana remained between 48-50 percent, while producer shares of the FOB price in other major cocoa producing countries such as Brazil, Dominican Republic, Ecuador, Indonesia, Malaysia and Nigeria were between $82-92$ percent. 
Figure 2. Ratio of cocoa producer price to FOB price in major producing countries (1995)

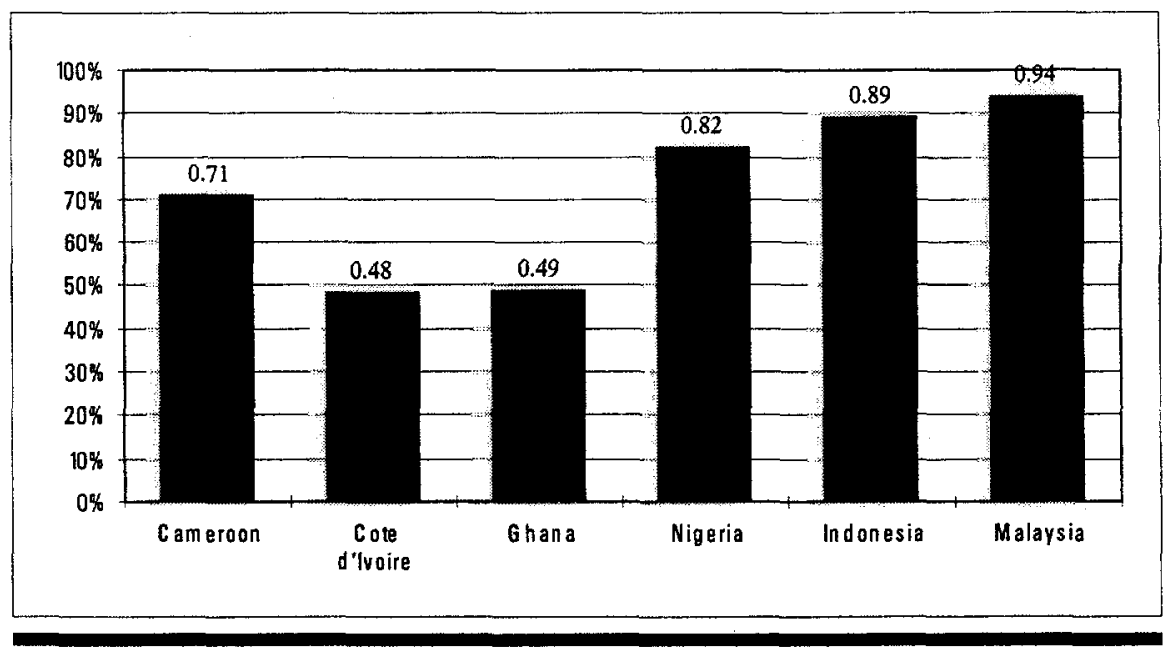

Source: Schreiber and Varangis (1995).

Hanak-Freud and Freud (1996) argue that producer prices are low in Cote d'Ivoire because of high export taxes. This is only partly true, however, as producer prices are still below those in other countries even when export taxes are considered. During the six seasons from 1993/94 through 1997/98, the explicit export tax (the DUS) in Cote d'Ivoire was approximately 22 percent of the FOB price and the average share of producer price to the FOB price was 49 percent, yielding a total of tax plus producer share to the FOB price of 71 percent. This is below producer price shares of the FOB price in other producing countries with the exception of Ghana.

Another feature of the barème, which we cannot quantify precisely, clearly discriminates against farmers. The barème pays exporters for shipping costs (insurance and freight; I\&F) that exceed market rates. Given that the CIF price is competitively determined on world markets, the higher I\&F costs thus artificially lower the FOB price which is used to determine producer prices. Based on discussions with shippers and on comparisons with market freight rates, CAISTAB's barème calculations of freight and handling costs are well above those actually paid by shippers.

\section{Are Forward Sales Valuable?}

Forward sales of cocoa are a linchpin of the Ivorian system in that they permit CAISTAB to fix incomes of producers and other agents. There are two key advantages claimed for forward sales: a) a risk benefit in that forward sales allow the government to offer a fixed annual price to farmers and hence to reduce risks to the latter; and b) an income benefit in that they improve total export revenues because 
forward prices for cocoa tend to be higher than spot prices ${ }^{6}$. We evaluate first the risk benefit to producers and then the income benefit to the economy as a whole.

\section{The Ivorian forward sales mechanism}

Cote d'Ivoire sells much of its expected crop forward through a method known by the French acronym PVAM (Programme de Ventes Anticipées à la Moyenne). The PVAM is designed to spread forward sales evenly throughout the season in order to achieve an average CIF price; in theory it does not attempt to achieve a higher than average CIF price (i.e., to "beat the market"). CAISTAB manages the PVAM on behalf of the Ivorian government as follows:

CAISTAB decides the quantities of export rights (known as déblocages) to sell for a given contract execution date, for example, October-December;

CAISTAB auctions the déblocages through an electronic trading system in Abidjan to firms holding valid export licenses?;

The purchase of the déblocage amounts to an FOB price guarantee to the exporter;

Once exporters have bought déblocages in the auctions, they are assumed to sell a corresponding export contract in New York or London in order to hedge their sale price risk;

If the actual sale price at which the contract is executed exceeds the guaranteed FOB price, the exporter repays the difference (called a reversement) to the CAISTAB; and

If the actual sale price at which the contract is executed is less than the guaranteed FOB price, the exporter receives the difference (called a soutien) from the CAISTAB.

A positive reversement implies that the stabilization margin (the variable $S$ in equation $\{2\}$ ) is positive; a positive soutien implies that the stabilization margin is negative.

${ }^{6}$ Although some analysts claim an additional benefit in that forward selling improves government budgeting because it allows the government to hedge its income from cocoa, this does not apply in Cote d'Ivoire because the export tax is specific, not ad valorem. In principal, however, even with ad valorem export taxes, the same benefit of forward sales is available to governments with liberalized agricultural sectors who have the option of choosing to hedge their tax revenues. They can do this by selling futures forward, to the value of the price exposure of their tax revenues, and then closing out the futures positions (buying back the futures contracts) as taxes become receivable. The extent to which they should hedge will depend on the tax take from the commodity export revenues, and the degree of progression in export tax rates. Thus, the use of futures markets provide similar benefits to forward sales for the government of Cote d'Ivoire to hedge its cocoa export tax revenues if taxes become ad-valorem.

${ }^{7}$ The electronic auction system was introduced in May 1996; before that date, déblocages were allocated through private negotiations between CAISTAB officials and exporters. 
Forward sales through the PVAM are in essence mandatory for private exporters because déblocages are mandatory for all exports. One argument for mandatory forward sales is that their benefits cannot now be gained by private agents because of market failure. The reasoning is as follows. Forward sellers usually must put up the crop, or some entitlement to the crop such as a warehouse receipt, as collateral. In the absence of a margin system, collateral is required because sellers have an incentive to renege on the forward contract if prices subsequently rise or if they cannot obtain the quantity for delivery. The existence of performance risk (i.e., the risk of non-delivery) allows forward selling only if the seller has a good credit standing, if collateral is adequate, or if margins are high enough. In the absence of physical inventories, exporters will only be able to sell forward if they have a forward contract to buy from producers. However, domestic forward markets do not exist due to performance risk and poor contract enforcement. Performance risk is higher where there are many small growers, poorly functioning domestic financial institutions and weak legal contract enforcement, all of which are characteristic of the Ivorian economy. Difficulties in reducing performance therefore makes forward selling difficult by private agents and justifies, in theory, some form of public action to reduce that risk.

The performance risk in forward sales is indeed reduced by the intervention of CAISTAB. CAISTAB, by controlling exports through the sale of déblocages, can be confident of the crop it will have for sale, and hence of the aggregate performance risk, in the coming season. Because of CAISTAB's established reputation in the market as a reliable counterpart, it is able to sell forward well of harvest, sometimes as far as 18 months.

Evidence for this market failure is that forward sales of cocoa have declined, in volume and period of coverage, after liberalization. In Cameroon and Nigeria forward sales have almost disappeared and the few remaining forward sales are for short periods ${ }^{8}$.

\section{The producer risk benefit of forward sales}

Ivorian cocoa producer prices have been fixed nominally within seasons and hence stabilization has been successful in that sense (for example, Diop-Boare 1994). The question remains: are the benefits from stable, but lower, prices greater than those from variable, but higher, prices? One way to evaluate the risk-return trade-off to the producer is the Newbery and Stiglitz (1981) approach, which is to calculate the certainty equivalent (CE) producer price. The CE price is that guaranteed price (as is theoretically available for cocoa in Cote d'Ivoire) at which risk-averse farmers would be indifferent compared to a variable market price.

The CE price is calculated from

$$
P_{c e}=\underline{P}\left(\exp \left[-\left\{\varepsilon+0.5 R(\varepsilon-1)^{2}\right\} \sigma^{2}\right]\right)
$$

\footnotetext{
${ }^{8}$ Also, in coffee, where in almost all producing countries the private sector is solely in charge of marketing and exports, forward sales are relatively low and cover no more than four to five months ahead.
} 
where $P_{c e}$ is the real quarterly CE cocoa price, $\underline{P}$ is the average observed real world price each quarter, $\varepsilon$ is the iso-elastic short-run price elasticity of demand, $\sigma$ is the coefficient of variation of real quarterly world prices, and $\mathrm{R}$ is the relative risk aversion coefficient. The variable $\underline{P}$ is first calculated on a CIF basis from world market data (World Bank 1998) and then converted to a farm gate basis by subtracting maritime transport and direct domestic marketing costs. In terms of Table $1, \underline{P}$ would then be $714 \mathrm{~F} / \mathrm{kg}$ (i.e., the CIF price of $904 \mathrm{~F} / \mathrm{kg}$ minus maritime transport of $75 \mathrm{~F} / \mathrm{kg}$ minus direct domestic marketing costs of $115 \mathrm{~F} / \mathrm{kg}$ ). We refer henceforth to $\underline{P}$ as the "farm gate FOB price".

We note, first, that output is affected by stabilization, even though stabilization is within seasons, given that there is some weak short-term supply response for tree crops. Second, it is assumed that $\mathrm{R}$ is unity, indicating that farmers are moderately risk averse (based on extensive empirical evidence launched by Binswanger, 1978). Third, in the absence of price stabilization, the volatility of domestic producer prices would be that of international cocoa prices. With those assumptions, we construct counter-factuals in which intra-annual producer price variability increases from zero (perfect stabilization) to world levels (perfect transmission of international prices) for each season from 1993/94 through 1997/98.

The within season coefficient of variation of monthly world prices had a maximum of 8.1 percent in $1993 / 94$ and a minimum of 2.8 percent in $1994 / 95$. The absolute value of the short-run price elasticity of demand is assumed to be 0.5 . Counter-factual stabilization benefits expressed relative to the $\underline{P}$ from equation (1) would therefore have ranged from a maximum of 0.3 percent of $\underline{P}$ in 1993/94 to a minimum of zero in 1994/95. This range of benefits can be compared to the structure of export pricing from 1993/94 through 1997/98 expressed as a share of FOB: producer price, 49 percent; explicit export taxation, 22 percent; direct domestic marketing costs, 14 percent; CAISTAB's operating costs, 6 percent; and stabilization profits, 10 percent. Assuming for the moment that the average 22 percent of explicit export taxation was justified, farmers were further taxed some 16 percent of the world price ( 6 for CAISTAB costs and 10 for stabilization profits) and received stabilization benefits of less than 1 percent of world price. In the absence of stabilization, but with the same explicit export tax, farmers ought to have received a producer price at least 15 percent higher (in terms of the FOB price) or $125 \mathrm{~F} / \mathrm{kg}$ in absolute terms.

The same result can be visualized over a longer period in Figure 3, which portrays the observed real official producer price of cocoa, the farm gate FOB price $(\underline{P})$, and the certainty equivalent price $\left(P_{c e}\right)$ by quarters from 1983 through 1997 . The certainty equivalent price is close to $\underline{P}$ given that quarterly prices vary little within crop seasons. The CE price is generally above the official minimum before 1989. A period of exceptionally low world prices occurred after 1989 and the CE price and the minimum were much closer then until 1993 or so when world prices rose again. In the 60 quarters observed from 1983 through 1997, in only nine did the producer price exceed the CE price. 
Figure 3. Real quarterly farm gate $F O B, C E$ and producer cocoa prices (1990 US\$/mt)

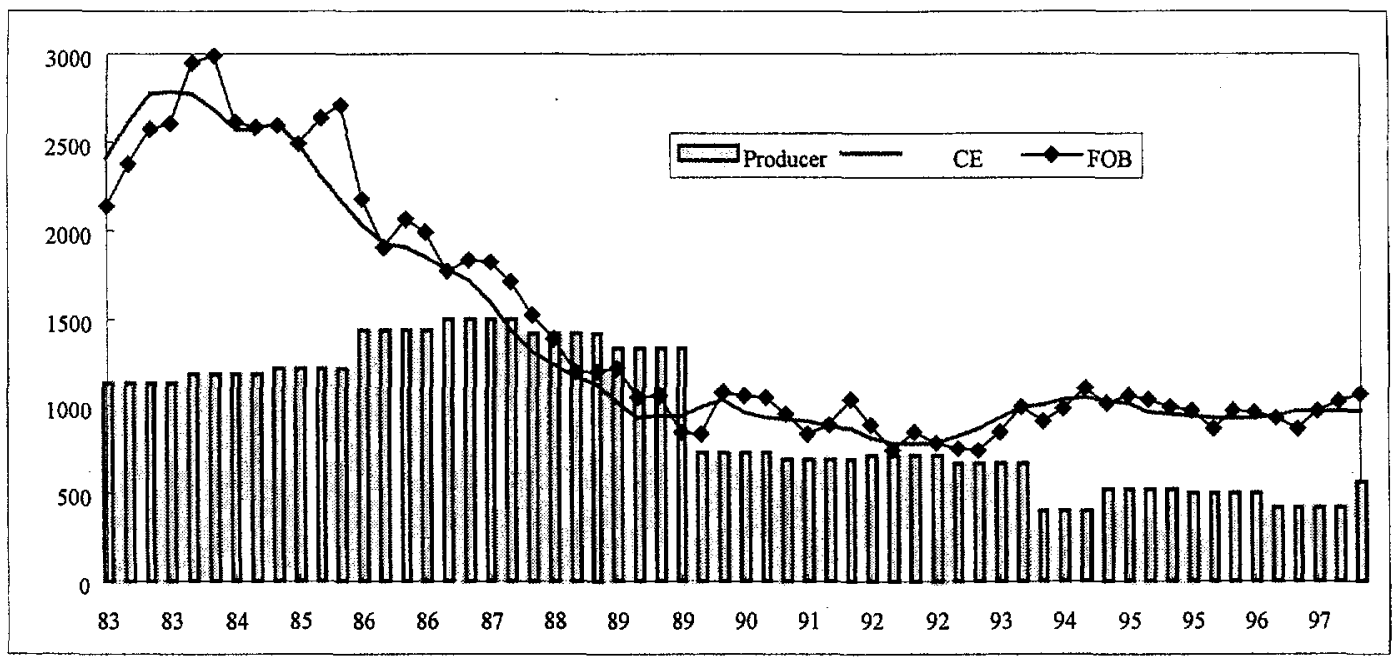

Source: Authors' calculations.

The income benefit of forward sales

A second benefit claimed for forward sales is that they allow exporters a forward premium. From the mid 1980s through the mid 1990s, the world market was in relatively abundant supply. With stocks carried forward, forward prices have generally been higher than prices for spot or nearby deliveries ${ }^{9}$. This implies that producing countries could indeed receive higher prices by selling forward, i.e., the existence of a positive premium.

The forward premium is not necessarily positive, however. Futures prices may indeed be either upward (downward) biased, in that they might fall (rise) as maturity approaches. Gilbert (1997) argues that, if short hedging (selling futures to hedge) outweighs long hedging (buying futures to hedge), speculators will tend to be net long (bought futures), and the futures price (of the same contract) must rise over time (as it approaches expiration or delivery) to give a hedging profit. Where long hedging dominates, speculators will be net short and futures prices will fall towards maturity.

Gilbert (1997) analyzed London cocoa market data from 1989 through $1996 . \mathrm{He}$ found that the average November price of the December futures contract was 5.2 percent lower than its February average, 4.7 percent lower than its May average and 3.3 percent lower than its August average. This suggests an upward biased futures price consistent with long hedging. ${ }^{10}$ The comparable figures for March were 4.4 percent higher in February, 3.3 percent higher in May and 2.3 percent higher in

\footnotetext{
${ }^{9}$ The forward price is based on the futures price for the relevant month plus or minus a quality premium. Nearby refers to the closest to delivery futures contract which may mean for immediate delivery or for delivery in a month or two. For practical purposes, a nearby contract is very close to being a spot contract.

${ }^{10}$ However, Gilbert (1997) notes that hedgers have usually been net short, suggesting that speculators have consistently lost money in the cocoa market over this period.
} 
August. Because the mean differences between contract prices were not statistically significant, Gilbert (1997, p.46) concluded that the argument that producing countries gain in terms of higher export prices by selling forward should be judged as "not proven".

We further compared different futures positions to spot with the same data. Table 2 shows that only the averages of the two most remote positions were significantly different from spot. Figure 4 plots the difference of the third, fourth, and fifth positions against spot; if spot is December, then the third corresponds to the following March. The three series are obviously closely related and the difference between further and nearby positions can be either positive or negative. Based on this analysis and other studies, the evidence for a statistically significant forward premium is at best inconclusive.

Table 2. Cocoa Price Analysis of Variance

\begin{tabular}{lcc}
\hline Position & $\begin{array}{c}\text { Average price } \\
(\mathfrak{f} / \mathrm{mt})\end{array}$ & $\begin{array}{c}\text { Average difference } \\
\text { from spot (percent) }\end{array}$ \\
\hline Spot & 834.2 & 0.0 \\
Position 2 & 853.9 & 2.4 \\
Position 3 & 858.1 & 2.9 \\
Position 4 & 859.9 & 3.1 \\
Position 5 & 877.5 & 5.2 \\
Position 6 & $889.9^{*}$ & 6.7 \\
Position 7 & $899.3^{* *}$ & 7.8 \\
\hline
\end{tabular}

Source: LIFFE monthly data from December 1990 through May 1997.

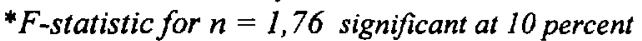

** F-statistic for $n=1,76$ significant at 5 percent 
Figure 4. Average Monthly Difference over Spot (£/mt)

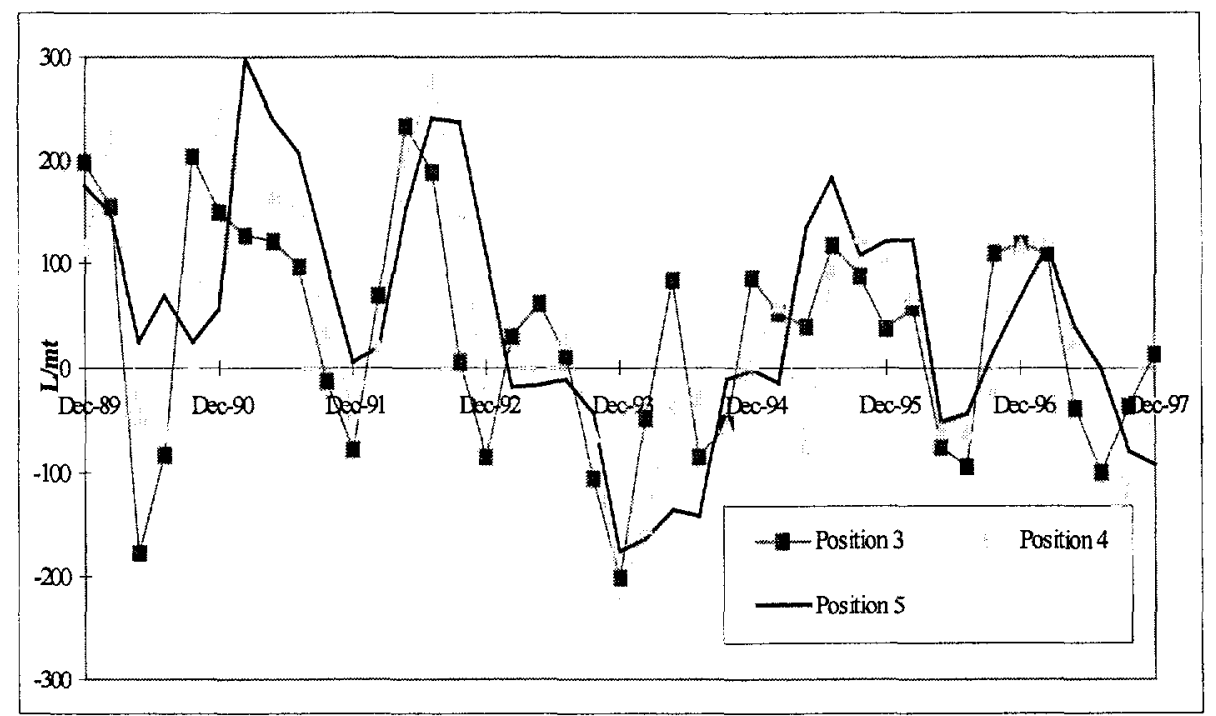

Source: Authors' calculations from LIFFE monthly data from December 1990 through May 1997.

Even if the forward price exceeds spot, the net benefits of forward sales may be negative if there are significant costs associated with selling forward. The net benefits of forward sales of cocoa are determined by the relation between the spot price and forward prices, by storage costs including financing, and by the availability of physical cocoa for export. We present two models of forward sales (denoted by $\mathrm{M}_{1}$ and $\mathrm{M}_{2}$ ). The gross benefits of the first model are only due to regular sales, that is selling forward evenly throughout the year, and not to the existence of the forward premium. The second model, is to quantify the income benefits (forward premium) that private exporters might obtain by selling forward in a liberalized export system. In the first model, CAISTAB sells forward through the PVAM. The net benefits of $\mathrm{M}_{1}$ are the difference between the average price realized by selling forward regularly and the spot price, less the unit costs of operating the $P V A M$. In the model $\mathrm{M}_{1}$, there is no forward premium because CAISTAB does not hold the physical cocoa and there are no physical storage costs.

In the second model, private exporters buy physical cocoa and then choose between selling immediately at the spot price and selling forward at a price which differs from spot by the amount of the forward premium. Because most physical cocoa is available during the main harvest from mid-October through February, we limit our analysis of $\mathrm{M}_{2}$ to an exporter who has cocoa in December or March and can sell spot at the December or March price or forward for future delivery. In model $\mathrm{M}_{2}$ there is a forward premium and its sign -- positive, negative, or zero -- is an empirical question. 
The net benefits of $M_{1}$ are

$$
\Pi_{1}=P_{f l}-P_{1}-C_{1}
$$

where $P_{f l}$ is the average $P V A M$ price, $P_{l}$ is the average spot price, and $C_{l}$ is the unit cost of the $P V A M$. The benefits of the $P V A M$ over the average spot price derive from a disciplined strategy of forward sales and are unrelated to the forward premium. The net benefits are the gross benefits less the costs of operating the program and the additional maritime transport and direct domestic marketing costs incurred through the barème. In terms of Table $1, P_{f l}$ is the CIF price of $904 \mathrm{~F} / \mathrm{kg}$ and $\mathrm{C}_{1}$ corresponds to those of CAISTAB's operating costs that are directly related to the $P V A M^{11}$.

The price $P_{f l}$ could not be directly observed ${ }^{12}$ over many years but has been calculated from a simulation study of the PVAM (Marquet 1997) for 1979 through 1996. According to the study, the average simulated $P V A M$ price would have been 1.9 percent higher than the average spot $\mathrm{CIF}$ price of equivalent quality cocoa. We use that figure to calculate the gross benefits of public forward sales in $M_{1}$ (Table 3).

In estimating the net benefits of the PVAM we assume:

- Cote d'Ivoire sells 1 million metric tons at an average CIF price of US $\$ 1507$ per metric ton; the latter price is roughly the average PVAM price for 1997/98;

- The average $P V A M$ price is 1.9 percent higher than the spot CIF price (as calculated from Marquet 1997);

- The operating expenses of CAISTAB related to the PVAM are some US\$ 16.7 million (about 10 billion CFA francs at an average exchange rate of $600 \mathrm{CFAF} / \mathrm{US} \$)^{13}$;

- The "excess marketing costs" are estimated at 5 percent of the FOB price, or some US\$69 million; and

- The producer price is the $1997 / 98$ minimum indicative price of $455 \mathrm{~F} / \mathrm{kg}$ (US\$758/mt).

\footnotetext{
"Some two-thirds of CAISTAB's average operating costs of $49 \mathrm{CFAF} / \mathrm{kg}$ in Table 1 are for subsidies to industrial processing of cocoa beans and to repayment of debt to exporters accumulated during the price slump of the 1980 s.

${ }^{12}$ The price $P_{f l}$ is the weighted average of contract prices, where the weights are quantities sold by CAISTAB at each position. It cannot be observed for previous seasons because CAISTAB has not always reported the quantities sold by position.

${ }^{13}$ Debt service is excluded. It could be argued that it should be included as the cost of past errors in judgment in managing the forward sales program.
} 
Table 3. Net benefits of Ivorian public forward sales (Model 1)

\begin{tabular}{lc}
\hline & \\
Calculation of gross benefits & $1,9 \%$ \\
Average price gain $(P V A M$ - spot) & 1,000 \\
Quantity exported (mmt) & 1,507 \\
Average CIF PVAM price $(\$ / \mathrm{mt})$ & 1,479 \\
Average CIF spot price $(\$ / \mathrm{mt})$ & 1,387 \\
Average FOB price $(\$ / \mathrm{mt})$ & 28.1 \\
Total gross benefits (millions of $\$$ ) & \\
Costs of $P V A M$ (millions of $\$$ ) & 16.7 \\
CAISTAB operating costs & 69.3 \\
Excess marketing costs $(5 \%$ of FOB) & -57.9 \\
& $-7.6 \%$ \\
Net benefits (millions of $\$$ ) & \\
Net benefits as \% of producer income & \\
\hline
\end{tabular}

Note:: Table may contain rounding errors.

Source: Marquet (1997), CAISTAB (1998) and authors' calculations.

The "excess marketing costs" are defined as the difference between the levels specified in the bareme and the levels that would be observed in competitive markets. The excess arises out of the barème negotiations between CAISTAB and exporters ${ }^{14}$. The regulated costs within the barème are, as explained previously, a necessary feature of the $P V A M$ because exporters cannot hedge their future domestic costs, including the price at which they buy from farmers, through market transactions; hence, they must fix those costs through an administered price structure, such as the barème. In theory marketing costs within the barème could be determined competitively and the excess would then be zero; in practice, they are fixed during secret negotiations between CAISTAB officials and exporters. This price-fixing is insulated from competition so that exporters' declared costs, and the profit margins based on declared costs, are inflated. The inflated margins have two parts -- one is a pure transfer from producers to exporters, and is not a social cost; the other is a social cost that would be eliminated through competitive pricing. It is only the second part that we define as "excess marketing costs".

Excess marketing costs are in fact likely to exceed 5 percent of FOB. Ivorian marketing costs appear to be at least double those found in cocoa producing countries with liberalized marketing systems, where the sum of marketing costs is about 15

\footnotetext{
${ }^{14}$ Cameroon prior to the 1994 reforms had a cocoa marketing system very similar to Cote d'Ivoire's based on the concept of the Caisse de Stabilization. As in Cote d'Ivoire the system used the barème to determine the producer price by deducting marketing costs and margins. The system also used forward sales aiming at stabilizing producer prices. In Cameroon after market liberalization and the elimination of the marketing agency ONCPB, cocoa producer prices rose by 40-50 percent relatively to those in Cote d'Ivoire. According to Gilbert (1997), two thirds of this difference is due to reductions in Cameroonian marketing costs with the reminder being due to lower taxation.
} 
percent or less of the FOB price ${ }^{15}$. Many studies have observed high operating costs of marketing boards or public stabilization funds compared to competitive systems (e.g., Duncan and Jones (1993).

The relative net benefits of $\mathrm{M}_{2}$ are:

$$
\Pi_{2}=\left\{P_{f 2} /\left(1+m C_{2}\right)-P_{2}\right\} / P_{2}
$$

where $P_{f 2}$ is the forward price of $\mathrm{M}_{2}, m$ is the fraction of the year spent in storage, $P_{2}$ is the spot price for December/March sales, and $C_{2}$ is the cost of financing and physical storage over the storage period, relative to $P_{f 2}$. The value of $C_{2}$ is taken as 0.13 , including an annual domestic rate of interest of 10 percent and 3 percent annual physical storage costs. We note that $C_{2}$ includes only private costs and does not include the costs incurred in operating the PVAM.

Table 4 reports returns to private forward sales. None of the mean net benefits is significantly different from zero at the 10 percent level. Hence, private agents would probably not have had an incentive to sell forward unless there are risk benefits which we have not attempted to quantify here, or unless they had access to cheaper external financing of their stocks.

Table 4. Relative net benefits of private forward sales of cocoa (in percentage of December and March spot price) from $1989-1997$

\begin{tabular}{lrrr}
\hline & \multicolumn{3}{c}{ Position } \\
& 2 & 3 & 4 \\
\cline { 2 - 4 } Gross benefit/spot price & 4.6 & 6.5 & 6.5 \\
Relative cost/spot price & 3.3 & 5.4 & 7.6 \\
Net benefit/spot price & & & \\
$\quad$ Mean & 1.3 & 1.0 & -1.0 \\
T-statistic & 0.693 & 0.330 & -0.255 \\
\hline
\end{tabular}

\section{The Effects of Tax and Marketing Reforms}

The government plans to eliminate the official price and cost structure (the barème), public forward sales (the PVAM), and the stabilization margin at the beginning of the 1999/2000 season. It is considering a reduction in the explicit export $\operatorname{tax}(D U S)$. As we have previously analyzed the PVAM, in this section, we discuss the likely effects of eliminating the bareme and the stabilization margin at different levels of the DUS.

\footnotetext{
${ }^{15}$ This was observed some time ago by Ruf and Milly (1990). Major cocoa producing that do not use marketing agencies are Brazil, Cameroon (after the 1994 reforms), the Dominican Republic, Ecuador, Indonesia, Malaysia, and Nigeria (after the 1986 reforms).
} 
The importance of cocoa in the Ivorian economy means that a partial equilibrium analysis can be misleading however. First, it excludes interactions between cocoa and other rural goods, and the industrial and service sectors. Second, the fiscal impact of price and tax policy for cocoa is large because of its share in present government income. In this section we investigate the economic effects of cocoa taxation and marketing policy with a computable general equilibrium (CGE) model $^{16}$.

The model begins with a modified social accounting matrix depicting the economy at the end of 1996 (summarized in Annex 1). In this model, an initial equilibrium exists where household income equals consumption plus savings plus net transfers; the value added from labor, land and capital in goods production is equal to the household endowments of those factors; exports equal imports plus net foreign savings (aid) minus debt service; and government revenue equals government consumption plus net foreign savings and net transfers to households minus debt service.

Goods production. There are 28 goods production sectors. Agricultural sectors are cocoa, coffee, forestry, food crops, other primary products (including livestock, fisheries, other perennial exports). Goods are produced by nested constant elasticity of substitution (CES) functions. Ignoring taxes for the moment, for any goods sector, $\mathrm{Q}_{\mathrm{i}}$, the production function is:

(4) $Q_{i}=\left[\left\{\delta_{i r} L_{i r}-\psi+\delta_{i x} L_{i u}^{-\psi}+\delta_{i k} K_{i k}-\psi+\delta_{i n} N_{i}^{-\psi}\right\}^{-1 / \psi}\right]+\sum_{j} G_{i j}^{a}$

The term in square brackets is the nest for value added from primary factors; $L$ indicates labor ('u' for urban, ' $r$ ' for rural), $K$ capital, $N$ land, and $\psi$ is a parameter such that $\psi=1 / \sigma-1$ where $\sigma$ is the elasticity of substitution among factors. The term $G_{i j}^{a}$ is the aggregate of intermediate inputs into production and the elasticity of substitution between $\mathrm{G}$ and factors is zero ${ }^{17}$.

Land is used only in rural goods. Both rural and urban labor produce rural goods because the value of agricultural output has two components. The first is on-farm output produced with land and rural labor. The second is the additional value of output between farm gate and FOB, which is produced by urban labor and capital.

\footnotetext{
${ }^{16}$ A similar model has been used by Chia et al (1992) to investigate poverty issues in Cote d'Ivoire.

${ }^{17}$ There are some differences between the present model and that of Chia et al (1992). In our model labor is not differentiated by skill level; our model imposes a constant elasticity of substitution among factors equal to 0.5 in all rural goods (coffee, cocoa, cotton, forestry, fisheries, other agricultural exports, food crops) and to 0.8 in all urban goods (the 21 sectors of industry and services), while the corresponding elasticity varies between 0.4 and 0.9 across sectors in Chia et al; our model is based on the 1995 input-output matrix of Cote d'Ivoire and 1996 national accounts data, while that of Chia et al uses 1986 data. Both models assume zero substitution between primary factors and intermediate goods.
} 
The treatment of taxes varies by the type of tax (Rutherford 1994). Indirect taxes on intermediate goods are net (i.e., they raise producer cost), while trade taxes on outputs are gross (i.e., they lower producer price). Equation (4) is modified to account for taxes by

(4a) $Q_{i}\left(1-\tau_{i}^{x}\right)=\sum_{f} V A_{f}+\sum_{j} G_{i j}^{a}\left(1+\tau_{i j}\right)$

where VA is value added from primary factors, $\tau_{i j}$ is indirect taxes on inputs and $\tau_{i}^{x}$ is the rate of export tax. Export taxes are paid only on coffee and cocoa and there are no factor taxes.

Households. Five household classes supply primary factors, consume, save, invest, and receive government transfers. Classes are food crop producers (denoted as $F C$ ), export crop producers $(X C)$, all other agricultural producers $(O A)$, urban formal (UF), and urban informal $(U N)$, defined by primary residence and source of income. For simplicity we have excluded cash crops from the income sources of $F C$ households. This is admittedly unrealistic as all rural households have some cash crop income. But the classification is respected if one understands that the $\mathrm{FC}$ households produce none or very little of the major export tree crops (cocoa, coffee, rubber, oil palm, and bananas). The $O A$ households are a residual category of specialized livestock producers, fishermen, foresters, and rural artisans.

Households supply four factors: rural labor $(F C, X C$, and $O A$ ), urban labor (UF and $U N$ ), land, and capital. Food crop producers receive no income from export crops, but export crop producers do receive some income from food crops; for example, many farmers raise food crops on farms where the primary good is cocoa or coffee.

Rural households. Rural households are about 56 percent of the population (Annex 1 shows the distribution of households across classes). Smallholders -defined as related individuals living and working on owned or rented land with mainly their own labor -- dominate the rural sector. The plantation sector is confined to the humid south, usually for production of oil palm and rubber. Those who are largely food crop producers (the $\mathrm{FC}$ households) are some 24 percent of the population. While they live throughout the country, they are most characteristic of the less humid north. The climate of the North is less productive, in the sense of giving lower yields of food crops and livestock and in forbidding production of the more lucrative tree crops. The FC households own 40 percent of value added (VA) from land and some 26 percent of VA from labor. Those who are mainly export producers are only 20 percent of the national population, but receive 45 percent of aggregate VA from land. The XC households have larger farm sizes (Benjamin and Deaton 1993: p. 302) and, by definition, grow the highest-valued crops. This class is a net importer of labor, mainly from the other two rural classes.

The urban households are 45 percent of the population, of which 10 percent is in the formal sector and 35 percent in the non-formal. Income is concentrated in the formal, which takes 25 percent of all labor income, 60 percent of capital income and 
about 36 percent of aggregate savings. Informal households hold some 24 percent of the capital stock, mainly in small-scale services and manufacturing, and take a little more than one-half of aggregate labor income.

Household income $Y_{h}$ for class ' $h$ ' is defined as $\Sigma_{f} Z_{f h}+V_{h}$, where $Z_{f h}$ is each household's factor endowment and $V_{h}$ is its net transfer from the government, where the latter two are as shown in Annex 1. Households consume goods and services through a nested CES consumption function. In the lower nest, households consume a composite good, $G_{i h}^{a}$, of imports and domestic goods such that for any class of households

(5) $G_{i h}^{a}=\left[\beta_{i h}^{m}\left(Q_{i h}^{m}\right)^{-\omega}+\beta_{i h}^{d}\left(Q_{i h}^{d}\right)^{-\omega}\right]^{-1 / \omega}$

where $\beta$ is the budget share, $\omega$ is the substitution parameter equal to $0.5, Q^{d}$ is a domestic good and $Q^{n}$ is an imported good. The composite good produces utility for households from

$$
U_{h}=\Sigma_{i} \varsigma_{h i} \log \left(G_{i h}^{a}\right)
$$

where $\zeta_{\text {hi }}$ is the class share in the national consumption of a composite good. The household budget constraint is

$$
\text { (7) } \quad \Sigma_{i}\left(P_{i} * G_{i h}^{a}\right)=Y_{h}-S_{h}-V_{h}
$$

where $P_{i}$ is the price of the composite good.

Savings and investment. Domestic savings are the total of savings by export crop producers and the urban classes. Food crop producers and other agricultural producers do not save. Domestic savings is equal to new fixed investment net of (constant) depreciation. The savings investment balance is then $\Sigma S_{h}=I$. Net foreign savings, $S F$, is $X+A-M-D$, assuming that there are no net unrequited public or private transfers ${ }^{18}$. The variable $A$ is gross aid flows and $D$ is gross debt service (principal and interest). The government rebates net foreign savings to consumers through a lump sum transfer, shown in Annex 1 as "household transfers". The value of $I \equiv v \Sigma$ ${ }_{i} Q_{i u}$ where $v$ is the rate of new net investment. Investment is a fixed proportion of output in the industry, service, and mining/petroleum sectors and is zero in rural goods.

\footnotetext{
${ }^{18}$ The volume of net public transfers is in fact small. That of net private transfers is large, but because private transfers consist largely of unrecorded labor remittances, its volume cannot be reliably included in the model.
} 
Foreign trade. Imports are produced with foreign exchange. Imports and domestic goods are transformed into domestic supply with CES functions. Exports are produced with value added and intermediate goods, as in equation (4). The allocation of exportables among exports, domestic consumption and government revenue through export taxes is:

$$
Q_{i}^{x}\left(1-\tau_{i}^{x}\right)=X_{i}+\sum_{h} G_{i h}^{x}+\sum_{j} G_{i j}^{x}
$$

where $Q_{i}^{x}$ is output of exportables gross of export taxes, $X_{i}$ is net exports, $G_{i h}^{x}$ is domestic consumption of exportables, $G_{i j}^{x}$ is the use of exportables as intermediate inputs, and $\tau_{i}^{x}$ is the export tax rate.

Government. The government's income is indirect taxes and foreign savings (the trade surplus and aid). Its expenditure is consumption of goods and services and foreign debt service. Any excess of income over expenditure is rebated to households so that the government's budget constraint is

$$
\text { (9) } R+(A-D)-C_{g}=\sum_{h} V_{h}
$$

where $R$ indicates revenue, $\mathrm{A}$ is aid, $D$ is foreign debt service (principal and interest), $C_{g}$ is government consumption, and $\sum_{h} V_{h}$ is the sum of government transfers to households. The variables $R$ and $C_{g}$ must be $\geq 0$, while $A, D$, and $\sum_{h} V_{h} \geq 0$; in the base data set, $A>0, D>0$ and $\sum_{h} V_{h}>0$ (Annex 1). Revenue is

$$
\text { (10) } R=\sum_{i}\left(X_{i} \tau_{i}^{x}+G_{i}^{m} \tau_{i}^{m}+\sum_{j} G_{i j}^{a} \tau_{i j}^{a}\right)
$$

The tax rate on cocoa in equation (10) has two parts. The first is the explicit export tax (the DUS). The second is the sum of the stabilization margin and allocations to CAISTAB reserves. This second part has two putative uses: ex-post producer price stabilization, and for marketing and other service costs. Because ex-post price stabilization is not paid and because CAISTAB's costs are neither competitively determined nor directly related to real services, the stabilization margin amounts to a second export tax ${ }^{19}$. The $1997 / 98$ DUS was 18.1 percent of FOB and the implicit export tax rate was 8.6 percent, giving a total taxation of 26.7 percent with respect to FOB $^{20}$.

\footnotetext{
${ }^{19}$ It may be objected that this revenue is in fact used to fund other government services, but this does not change the incidence of the cost with respect to coffee and cocoa producers; they are still taxed.

${ }^{20}$ The 18.1 percent is that shown in Table 1 ; the 8.6 percent includes the 7 percent for the stabilization margin
} 


\section{The optimal partial equilibrium export tax}

Projected long-term Ivoirian exports of $1.0 \mathrm{mmt}$ would give the country a share of 0.37 at projected world exports of $2.7 \mathrm{mmt}$. Given that market share, Cote d'Ivoire can improve national income from cocoa by setting an export tax so that the domestic producer price is the world price minus the export tax. With long-term values for the rest of the world (ROW) supply elasticity of 1.0, ROW demand elasticity of -0.6 , and a projected Ivorien world market share of 0.37 , the absolute value of the elasticity of demand facing Cote d'Ivoire (Trivedi and Akiyama, 1992) is

$$
\varepsilon_{d c i}=\left(\varepsilon_{d r o w}-(1-0.37)^{*} \varepsilon_{\text {srow }}\right) /(0.37)=3.32
$$

implying an long-term export tax of 30.1 percent, which is close to the current total of 26.7 percent.

\section{General Equilibrium Effects}

Given that the current total export tax from Cote d'Ivoire is reasonably close to the long-term optimum, one expects national income to decline with large changes in the current export tax. Hence, adjustments in the export tax would chiefly be redistributive unless there are real cost reductions associated with other policy changes.

Now we consider the general equilibrium effects. Table 5 summarizes five experiments involving the export tax and marketing costs. In the first three experiments, the total cocoa export tax (including the explicit export tax and the stabilization margin) varies from 10 to 15 to 20 percent of FOB. A fourth experiment holds the explicit cocoa tax at 17.5 percent (about two-thirds of the current total rate) and lowers direct domestic marketing costs by 5 percent. A fifth experiment lowers marketing costs by 10 percent, with the explicit export tax held at 17.5 percent, which is the ad-valorem equivalent of the DUS with respect to projected average world prices. The fifth experiment puts Ivorian marketing costs at a level similar to those of competitive systems.

With unchanged marketing costs, the lower export taxes basically redistribute income from urban to rural producers, as shown in experiments (1), (2), and (3) in Table 5. The redistributive effects work through the rise in rural wages induced by the higher cocoa profitability associated with lower export taxation. At a cocoa export tax of 10 percent (experiment 1), rural wages and land rents rise by between 18 and 20 percent. Those factor price shifts produce greater welfare changes among food crop producers and other agricultural producers than among export crop producers; this relative change is related to the sharp decline in coffee output associated with the rise 
in cocoa production, since cocoa and coffee are to some extent competitors in production.

We calculated an aggregate welfare index for each experiment in which the weights are the shares of each class in initial consumption. The shares (from Annex 1) are FC, .116; XC, .233; OA, 0.048; UF, 0.296; and UN, 0.307. Cutting the total export tax from the current total of 26.7 percent of FOB reduces the aggregate welfare index by 1.9 percent. Eliminating the implicit part of the export tax now levied through the stabilization fund and eliminating the barème so as to lower domestic marketing costs makes the aggregate welfare effect negligible and has a noticeable redistribiutive effect in favor of the poorer rural groups.

The government of Cote d'Ivoire receives about 13 percent of its annual revenue from the cocoa $D U S$, so it is unlikely that it would drop that levy completely. A more probable scenario is one in which it liberalizes export marketing and privatizes CAISTAB, thereby cutting internal and external marketing costs ${ }^{21}$ and eliminating the stabilization margin. This scenario is depicted in experiments (4) and (5) in Table 4, which show lower marketing costs by 5 and 10 percent respectively at an export tax of 17.5 percent. The lower marketing costs -- which consist partly of a transfer of rents from export license holders and marketing intermediaries to land owners and laborers who produce cocoa and partly of a real reduction in production costs -- allow producers a higher share of FOB. At the same DUS rate of 17.5 percent, lower marketing costs also have a lower opportunity cost in foregone coffee production, and produce very little change in aggregate welfare.

\footnotetext{
${ }^{21}$ The CAISTAB system is associated with a fixed rate for maritime transport, which makes most of the difference between the FOB and CIF prices. Hence, elimination of the fixed maritime transport rates in the bareme ought to raise the Ivorian FOB price even if the world CIF price does not change at all. Changes in marketing costs would benefit coffee as well.
} 
Table 5. Economic Effects of Changes in Export Tax and Marketing Costs of Cocoa

\begin{tabular}{|c|c|c|c|c|c|}
\hline Experiment number & (1) & $(2)$ & (3) & (4) & $(5)$ \\
\hline \multirow[t]{2}{*}{ Total export tax (percent) } & 10 & 15 & 20 & 17.5 & 17.5 \\
\hline & \multicolumn{5}{|c|}{ (percentage changes from base) } \\
\hline Marketing costs & 0 & 0 & 0 & -5 & -10 \\
\hline \multicolumn{6}{|l|}{ Value of output } \\
\hline Cocoa & 27.8 & 19.8 & 11.5 & 17.1 & 18.5 \\
\hline Coffee & -28.6 & -21.3 & -12.9 & -16.5 & -15.8 \\
\hline Other agriculture & -5.1 & -3.6 & -2.1 & -3.2 & -3.5 \\
\hline Industrial goods & -9.7 & -7.1 & -4.1 & -5.8 & -6.1 \\
\hline \multicolumn{6}{|l|}{ Welfare index } \\
\hline Food producers & 12.8 & 8.5 & 4.9 & 8.5 & 10.4 \\
\hline Export producers & 5.7 & 4.1 & 2.4 & 4.4 & 5.6 \\
\hline Other rural producers & 14.2 & 9.2 & 5.3 & 9.3 & 11.3 \\
\hline Urban formal & -8.0 & -5.5 & -3.0 & -4.5 & -4.8 \\
\hline Urban informal & -9.7 & -6.5 & -3.6 & -5.4 & -5.9 \\
\hline Weighted index & -1.9 & -1.2 & -0.6 & -0.5 & -0.2 \\
\hline \multicolumn{6}{|l|}{ Factor returns } \\
\hline Land rental & 21.4 & 14.6 & 8.2 & 14.1 & 16.9 \\
\hline Rural wages & 22.8 & 15.6 & 8.7 & 14.8 & 17.6 \\
\hline Urban wages & -2.8 & -1.9 & -1.0 & -1.4 & -1.4 \\
\hline Producer share of FOB & 0.77 & 0.73 & 0.69 & 0.72 & 0.74 \\
\hline
\end{tabular}

\section{Conclusions}

This paper has analyzed the cocoa marketing and pricing policies in Cote d'Ivoire. The paper looks into the cost of marketing, prices received by the farmers, and examines the producer price stabilization benefits. The paper also analyzes the net benefits from a publicly run system of export sales based on forward selling and uses a general equilibrium model to show the effects of reductions in export taxes and marketing costs. Based on the analysis performed, the following are some of the key conclusions.

First, we conclude unambiguously that cocoa price and marketing policy have reduced farmers' mean income for many years and continue to do so. The share of the Ivorien producer price to the FOB price and the absolute level of producer prices are the lowest among cocoa producers worldwide. The adjustment of producer prices with respect to the world price has not compensated growers in bad years for what they have lost in good years. In other words, the state has not used or managed the stabilization fund as it was intended. 
Much of the debate about stabilization hinges on whether farmers make the right choices about income fluctuations caused by exogenous price movements. The evidence, while far from complete, indicates that farmers use windfall gains rationally ${ }^{22}$. It is not necessarily true, therefore, that in the absence of government stabilization programs farmers will overspend, either on current consumption or on overinvestment in new plantings in response to temporarily high prices, as long as there are alternative economic activities.

The fixed intra-annual price provides comparatively little benefit to producers because it deals with the wrong source of variation. Most of the price variance is between years, not within years. Therefore, the annual minimum price can be eliminated, as its main function now is to create opportunities for corruption through harassment of traders and farmers during official attempts to enforce the minimum price.

Second, price and marketing policies have reduced farmers' mean incomes without compensating them adequately in terms of lower price risk. In other words, the government has stabilized farm revenues from cocoa only at a high cost in mean income.

Third, the costs of the public forward sales system (PVAM) outweigh its benefits. Proponents of the forward sales claim that it benefits producers because it allows a stable producer price and because forward prices are higher than spot. We find that mean producer prices under the $P V A M$ do not compensate for the lower price risk. The argument that Cote d'Ivoire gains higher prices by selling forward is found inconclusive, but the net benefits are conclusively negative.

Fourth, the farm price should and can be raised. There are two ways to do so: by lowering the export tax or by allowing competition to impose greater efficiency in marketing. Lowering the cocoa export tax would reduce national income slightly, however. Cote d'Ivoire has enough monopoly power in the world market that the income maximizing export tax is about 30 percent even taking into account general equilibrium effects.

Fifth, lowering the explicit export tax (the DUS) from current levels would have a small negative effect on national income. While the current explicit export tax of 1718 percent is well below the short-term optimal rate, raising the explicit export tax closer to the optimal rate would provoke a supply response from the other producers and eventually reduce Ivorian market share.

Sixth, lowering the cocoa export tax would improve the national income distribution. The improvement depends on the weights assigned to different household

\footnotetext{
${ }^{22}$ Hill (1963) argues that Ghanaian cocoa farmers are quite careful regarding wasteful consumption expenditures. Bevan, Collier and Gunning (1992), suggest that Kenyan coffee farmers understood the temporary nature of the coffee price boom in the late 1970 s and saved about 60 percent of their extra income. Bauer (1984) finds that farmers in periods of booms diversify into other activities.
} 
incomes. Because rural poverty is more severe than urban, weighted incomes at lower export tax rates would probably be welfare improving.

Seventh, raising the minimum producer price by making domestic marketing cheaper through more aggressive reforms would raise national income at a given export tax. Total Ivorian marketing costs -- including the indirect costs incurred by the operations of CAISTAB -- are high compared to other cocoa producing countries. Greater marketing efficiency can be achieved by eliminating the barème and would not have the indirect fiscal effect of raising taxes in other sectors.

We note an important indirect effect of a lower implicit export tax. This is the benefit to rural groups that do not produce cocoa. A cut in the export taxation of cocoa improves rural wages and hence benefits rural producers of food crops and other exports. Given the difficulties in achieving this desirable result by other means, this is not a trivial benefit.

There is another effect of the domestic pricing system which cannot be quantified, but which merits some comment. The barème and the minimum producer price, by imposing uniform costs throughout the domestic and foreign marketing chains, make price discovery and cooperative marketing by producers unprofitable. In so doing, they prevent the emergence of powerful producers' organizations capable of representing the interests of small Ivorien farmers and maintain those farmers in a perpetual state of dependence on the government and on the powerful and wellorganized private exporters. 
Annex 1. Supply and Demand Matrix for Cote d'Ivoire in 1996 (billions of CFA francs)

\begin{tabular}{|c|c|c|c|c|c|c|c|c|c|c|c|c|c|c|}
\hline & \multicolumn{8}{|c|}{ Goods sectors $(Q)$} & \multicolumn{4}{|c|}{ Factor endowments $\left[Z_{\text {gh }}\right]$} & \multirow[b]{2}{*}{$\begin{array}{c}\text { Savings } \\
{\left[S_{h}\right]}\end{array}$} & \multirow[b]{2}{*}{$\begin{array}{l}\text { Transfers } \\
\text { received }\left(V_{h}\right)\end{array}$} \\
\hline & $\overline{\text { Coffee }}$ & ocoa & Forest & $\begin{array}{l}\text { Other } \\
\text { Agric }\end{array}$ & $\begin{array}{l}\text { Other } \\
\text { Exports }\end{array}$ & Industry & Services & Minerals & Land & R. Labor & U. Labor & Capital & & \\
\hline Output $(Q)$ & 19.4 & 53.5 & 100.7 & 985.5 & 280.8 & 1795.0 & 2865.5 & 107.1 & & & & & & \\
\hline \multicolumn{15}{|l|}{ Value added from primary factors $\left[V A_{f}\right]$} \\
\hline Land $[N]$ & 67.2 & 266.4 & 19.3 & 594.3 & 112.2 & & & & & & & & & \\
\hline Rural labor $\left[L_{r}\right]$ & 22.4 & 132.2 & 16.4 & 231.1 & 84.3 & & & & & & & & & \\
\hline Urban labor $\left[L_{r}\right]$ & 5.8 & 28.6 & 0.1 & 6.3 & 3.9 & 204.6 & 870.6 & 30.4 & & & & & & \\
\hline Capital $[K]$ & 20.6 & 101.4 & 0.5 & 22.2 & 13.3 & 547.3 & 1018.2 & 56.6 & & & & & & \\
\hline Intermediate goods use $[G]$ & 89.2 & 309.9 & 82.1 & 147.1 & 136.2 & 1854.3 & 751.0 & 26.0 & & & & & & \\
\hline Taxes on intermediate goods $\left[\tau^{g}\right]$ & 0 & 0 & 8.3 & -12.9 & 2.0 & 237.7 & 381.8 & 0.6 & & & & & & \\
\hline \multicolumn{15}{|l|}{ HOUSEHOLDS (pop. 14.23 million) } \\
\hline \multicolumn{15}{|l|}{ Consumption $[C]$} \\
\hline Food crop (3.4 million) $[F C]$ & & & & 197.2 & 13.9 & 178.8 & 101.0 & & 423.7 & 126.5 & & & 0.0 & -58.0 \\
\hline Export crop (2.9 million) $[X C]$ & & & & 379.5 & 21.9 & 388.4 & 197.6 & & 476.7 & 277.2 & & 284.9 & 124.7 & 75.0 \\
\hline Other agricultural (1.6 million) $[O A]$ & & & & 79.5 & 5.6 & 77.2 & 40.8 & & 158.9 & 82.7 & & & 0.0 & -38.0 \\
\hline Urban formal (1.4 million) [UF] & & & & 126.1 & 8.5 & 568.0 & 547.2 & & & & 287.6 & 1068.2 & 159.3 & 59.4 \\
\hline Urban informal (5.0 million) [UN] & & & & 243.3 & 21.2 & 662.2 & 364.8 & & & & 862.7 & 427.3 & 154.8 & 165.3 \\
\hline Investment $\left[\mathrm{I}_{h}\right]$ & & & 10.1 & & & 120.5 & 308.1 & & & & & & & \\
\hline \multicolumn{15}{|l|}{ GOVERNMENT } \\
\hline \multicolumn{15}{|l|}{ Tax revenue $[R]$} \\
\hline Export taxes $\left(\tau^{n}\right)$ & 2.6 & 285.9 & & & & & & & & & & & & \\
\hline Import taxes $\left(\tau^{m)}\right.$ & & & 0.1 & 18.7 & 0.3 & 382.93 & & & & & & & & \\
\hline Consumption $[\mathrm{Cg}]$ & & & & & & 70.2 & 517.5 & & & & & & & \\
\hline \multicolumn{15}{|l|}{ Transfers to households [ $\mathrm{V}]$} \\
\hline \multicolumn{15}{|l|}{ Gross external debt service $[D]$} \\
\hline \multicolumn{15}{|l|}{ Aid $[A]$} \\
\hline \multicolumn{15}{|l|}{ FOREIGN TRADE } \\
\hline Exports $[X]$ & 185.9 & 784.9 & 26.0 & 2.4 & 71.5 & 1048.9 & 156.0 & 6.5 & & & & & & \\
\hline Imports $[M]$ & & & 0.4 & 187.2 & 0.0 & 1260.9 & 600.0 & 4.4 & & & & & & \\
\hline
\end{tabular}

Source: République de la Cote d'Ivoire (1997) 


\section{REFERENCES}

Akiyama, Takamasa. 1988. "Cocoa and Coffee Pricing Policies in Cote d'Ivoire". PRE Working Papers WPS 64.

Bauer, Peter, 1984. "Remembrance of Studies Past: Retracing First Steps.", in Gerald M. Meier and Dudley Seers, eds. Pioneers in Development. New York: Oxford University Press.

Benjamin, Dwayne and Angus Deaton. 1993. "Household Welfare and the Pricing of Cocoa and Coffee in Cote d'Ivoire". World Bank Economic Review. 3(7): 293-318.

Bevan, David, Paul Collier, and Jan Willem Gunning, 1992. "Anatomy of a Temporary Trade Shock: The Kenyan Coffee Boom of 1976-9". Journal of African Economies, Volume 1, Number 2. August.

Caisse de Stabilisation et de Soutien des Prix des Productions Agricoles. "Tableaux de Stabilisation". Mimeo. Abidjan. 1998.

Chia, Ngee-Choon, Sadek M. Wabah and John Whalley. 1992. "A General EquilibriumBased Social Policy Model for Cote d'Ivoire". Poverty and Social Policy Series Paper No 2. World Bank.

Deaton, A.S. 1992. "Commodity Prices, Stabilization, and Growth in Africa". Discussion Paper \#166. Center of International Studies, Woodrow Wilson School, Princeton University.

Duncan, Alex and Stephen Jones. 1993. "Agricultural Marketing and Pricing Reform: A Review of Experience". World Development. Vol. 21, No. 9, pp.1495-1514.

Diop-Boare, Abibatou. 1994. "Impact des Intervention Publiques sur l'Agriculture et la Croissance Economique de la Cote d'Ivoire". Cellule d'Analyse Politiques Economiques du CIRES. Document de Travail No. 14.

Gilbert, Christopher L. 1997. "Cocoa Market Liberalization: Its Effects on Quality, Futures Trading and Prices". The Cocoa Association of London. September.

Hill, Polly (1963). "The Migrant Cocoa Farmers of Southern Ghana: A Study in Rural Capitalism". Cambridge: Cambridge University Press.

Hanak Freud, E. and C. Freud. 1996. "Devaluation and liberalization as tools for enhancing competitiveness? Some insights from the recent West African experience in cocoa marketing". Documents de travail en economie des filieres No. 29. CIRAD November.

International Cocoa Organization (1998). "Review of Annual Forecasts of World Production and Consumption". Document of the International Cocoa Council. ICC/57/5. London. 1998.

Kouassi Atse Prosper (1997). "Caisse de Stabilisation de Cote d'Tvoire -- Réponses à Trente Années d'Interrogations". 2nd edition. Privately published. Abidjan. 1997.

Landell Mills Inc. Cote d'Ivoire - Etude sur l'Exportation du Cafe. Processed. October. 1996. 
London International Financial Futures and Options Exchange (LIFFE) various years. "No 7 Cocoa Futures Price History Data". LIFFE. London.

Marquet, Yannick. Programme de ventes anticipées à la moyenne et optimisation des recettes d'exportation: Le cas du cacao en Cote d'Ivoire, 1978-1996. Processed document. 1997.

Newbery, D. M. G and Joseph Stiglitz. "The Theory of Commodity Price Stabilization". Oxford University Press. 1981.

République de la Cote d'Tvoire. "Les Comptes de la Nation 1996". L'Institut National de la Statistique. Abidjan. 1997.

Ruf, Francois. "Booms et crises du cacao: les vertiges de l'or brun". Karthala. Paris. 1996.

Ruf, Francois and Hubert de Milly. "Comparison of Cocoa Production Costs in Seven Producing Countries". Paper presented at the ICCO's Advisory Group on the World Economy, Seventh Meeting, Accra, 18-22 June 1990.

Rutherford, Thomas F. "Applied General Equilibrium Modeling with MPSGE as a GAMS sub-system". University of Colorado. Processed. 1994.

Schreiber, Gotz and Panos Varangis. "Cocoa Marketing and Pricing Systems in West Africa”. World Bank. Processed. 1995.

Trivedi, P. K. and Takamasa Akiyama. 1992. "A Framework for Evaluating the Impact of Pricing Policies for Cocoa and Coffee in Cote d'Ivoire". World Bank Economic Review. 6(2): 307-30.

World Bank. 1996. "Poverty in Cote d'Ivoire: A Framework for Action". Report 15640-IVC.

World Bank. 1998. Commodity price data base. 


\section{Policy Research Working Paper Series}

Title

WPS2059 Financial Intermediation and Growth:
Causality and Causes

WPS2060 The Macroeconomics of Delayed Exchange-Rate Unification: Theory And Evidence from Tanzania

WPS2061 A Framework for Regulating Microfinance Institutions

WPS2062 Does Financial Reform Increase or Reduce Savings?

WPS2063 The Practice of Access Pricing: Telecommunications in the United Kingdom

WPS2064 Regulating Privatized Rail Transport

WPS2065 Exporting. Externalities, and Technology Transfer

WPS2066 Flight Capital as a Portfolio Choice

WPS2067 Multinational Firms and Technology Transfer

WPS2068 Quitting and Labor Turnover: Microeconomic Evidence and Macroeconomic Consequences

WPS2069 Logit Analysis in a Rotating Panel Context and an Application to Self-Employment Decisions

WPS2070 The Search for the Key: Aid, Investment, and Policies in Africa

WPS2071 The World Bank's Unified Survey Projections: How Accurate Are They? An Ex-Post Evaluation of US91-US97
Author

Ross Levine

Norman Loayza

Thorsten Beck

Daniel Kaufmann

Stephen A. O'Connell

Hennie van Greuning

Joselito Gallardo

Bikki Randhawa

Oriana Bandiera

Gerard Caprio, Jr.

Patrick Honohan

Fabio Schiantarelli

Tommasso M. Valletti

Javier Campos

Pedro Cantos

Howard Pack

Kamal Saggi

Paul Collier

Anke Hoeffler

Catherine Pattillo

Amy Jocelyn Glass

Kamal Saggi

Tom Krebs

William F. Maloney

Patricio Aroca González William F. Maloney

David Dollar

William Easterly

Jos Verbeek
February 1999

Date

February 1999

February 1999

February 1999

February 1999

February 1999

February 1999

February 1999

February 1999

February 1999

March 1999

March 1999
Contact

for paper

K. Labrie

31001

D. Bouvet

35818

A. Thornton 80409

A. Yaptenco 38526

G. Chenet-Smith 36370

G. Chenet-Smith 36370

C. Bernardo 31148

A. Kitson-Walters 33712

L. Tabada 36896

T. Gomez 32127

T. Gomez 32127

E. Khine 37471

M. Galatis 31177 
Policy Research Working Paper Series

Title

WPS2072 Growth, Poverty, and Inequality: A. Regional Panel for Bangladesh

WPS2073 Politics, Transaction Costs, and the Design of Regulatory Institutions

WPS2074 Light and Lightning at the End of the Public Tunnel: Reform of the Electricity Sector in the Southern Cone

WPS2075 Between Group Inequality and Targeted Transfers

WPS2076 Microdeterminants of Consumption, Poverty, Growth, and Inequality in Bangladesh

WPS2077 Change in the Perception of the Poverty Line during Times of Depression: Russia 1993-96

WPS2078 Valuing Mortality Reduction in India: A Study of Compensationg-Wage Differentials

WPS2079 is More Targeting Consistent with Less Spending

WPS2080 Monitoring Targeting Performance When Decentralized Allocations to the Poor Are Unobserved
Author

Quentin T. Wodon

Antonio Estache David Martimort

Antonio Estache

Martin Rodriguez-Pardina

Date

March 1999

March 1999

March 1999

Quentin T. Wodon

Quentin T. Wodon

Branko Milanovic

Branko Jovanovic

Nathalie 8. Simon

Maureen L. Cropper

Anna Alberini

Seema Arora

Martin Ravallion

Martin Ravallion

March 1999

March 1999

March 1999

March 1999

March 1999
Contaces por paper

ป. Eaciam! 80425

G. Cheret-Smith 36370

9. Chenet-Smith 36370

J. Sadami 80425

1. Badami 80425

C. Argayoso 33592

T. Tourougui 87431

P. Saúer 33902

P. Sader 33902 